\title{
KEMAMPUAN ADSORBSI ABU SEKAM PADI TERHADAP AIR DAN ASAM LEMAK BEBAS VIRGIN COCONUT OIL (VCO) DALAM KOLOM ADSORBSI
}

\section{[Adsorbtion Ability of Rice Husk Ash to Water and Free Fatty Acid of Virgin Coconut Olil (VCO) in The Adsorption Column]}

\author{
Laras M Sulo $^{1^{*}}$, Khairuddin ${ }^{1}$, Ruslan ${ }^{1}$ \\ 1) Jurusan Kimia, Fakultas MIPA, Universitas Tadulako, Palu \\ Jl. Soekarno Hatta Km.9, Kampus Bumi Tadulako Tondo Palu, Telp. 0451- 422611 \\ *)Coresponding author: Larassulo@gmail.com (085398982411)
}

Diterima 10 Mei 2018, Disetujui 9 Mei 2019

\begin{abstract}
A research has been conducted on the adsorption ability of rice husk ash to water content and free fatty acid of virgin coconut oil (VCO) in the adsorption column. The objective of this research is to get the ratio of coarse VCO to rice husk ash adsorbent in the column that produces VCO with water content, free fatty acid that meets SNI and yields VCO yield not less than $80 \%$. This study used a completely randomized factorial design (CRF design) with the effect of the amount of rice husk ash adsorbent $(5 \mathrm{~g}, 10 \mathrm{~g}, 15 \mathrm{~g}, 20 \mathrm{~g}, 25 \mathrm{~g})$ in in columns 2.5 and 3 inches. The result of research on column 2.5 inch of the lowest water content $(0.2 \%)$ was found on the weight of rice husk ash $25 \mathrm{~g}$ and free fatty acid content on $25 \mathrm{~g}$ ash husk ash was $0.1 \%$. And at column 3.0 inch the lowest water content was found on $25 \mathrm{~g}$ ash husk ash $0.1 \%$, and the lowest free fatty acid content on ash weight of rice husk $25 \mathrm{~g}$ was $0.2 \%$ and the best yield was $90 \%$.
\end{abstract}

Keywords: free fatty acid, rice husk ash adsorbent, moisture content, Virgin Coconut Oil

\begin{abstract}
ABSTRAK
Telah dilakukan penelitian tentang kemampuan adsorbsi abu sekam padi terhadap kadar air dan asam lemak bebas virgin coconut oil (VCO) dalam kolom adsorbsi. Penelitian ini bertujuan untuk mendapatkan rasio VCO kasar terhadap adsorben abu sekam padi dalam kolom yang menghasilkan VCO dengan kadar air, asam lemak bebas yang memenuhi SNI dan menghasilkan rendemen VCO tidak kurang dari $80 \%$. Penelitian ini menggunakan rancangan acak lengkap pola faktorial (RALF) dengan perlakukan pengaruh jumlah adsorben abu sekam padi $(5 \mathrm{~g}, 10 \mathrm{~g}, 15 \mathrm{~g}, 20 \mathrm{~g}$, dan $25 \mathrm{~g})$ dalam kolom berukuran 2,5 dan 3,0 inchi. Hasil penelitian pada kolom 2,5 inchi, kadar air terendah terdapat pada berat abu sekam padi $25 \mathrm{~g}$ yaitu $0,2 \%$, dan kadar asam lemak bebas pada abu sekam padi $25 \mathrm{~g}$ yaitu $0,1 \%$, sedangkan pada kolom 3,0 inchi kadar air terendah terdapat pada abu sekam padi $25 \mathrm{~g}$ yaitu $0,1 \%$, dan kadar asam lemak bebas terendah pada berat abu sekam padi $25 \mathrm{~g}$ yaitu $0,2 \%$ dan rendemen terbaik $90 \%$.
\end{abstract}

Kata kunci: asam lemak bebas, adsorben abu sekam padi, kadar air, Virgin Coconut Oil 


\section{LATAR BELAKANG}

Minyak kelapa murni atau dikenal Virgin Coconut Oil (VCO) merupakan hasil olahan dari daging buah kelapa (Cocos nucifera $\mathrm{L}$ ) tua segar yang diperoleh tanpa melalui pemanasan atau suhu tidak lebih dari $60^{\circ} \mathrm{C}$ dan tanpa melalui proses pemurnian secara kimia (chemical refining) serta tidak melalui proses deodorisasi (BSN, 2008).

Produksi minyak kelapa murni (VCO) dapat dengan berbagai cara antara lain cara pemanasan (Nodjeng et al., 2013), cara fermentasi (Mappiratu dan ljirana, 2010; Handayani et al., 2009; Satheesh dan Prasad, 2014 ), cara sentrifugasi (Wong dan Hartina, 2014; Abdurrahman et al., 2009), cara ultrasonik (Fatwatun et al., 2013) dan cara enzimatik (Effendi et al., 2012; Mansor et al., 2012). Skala dan metode produksi cenderung berpengaruh terhadap mutu VCO, seperti kadar asam lemak bebas dan kadar air. VCO dengan kadar air tinggi lebih mudah tengik pada penyimpanan yang disebabkan karena hidrolisis, sedangkan asam lemak bebas berpengaruh terhadap rasa dan aroma.

Standar Nasional Indonesia (SNI) mensyaratkan kadar air dan asam lemak bebas VCO maksimum 0,2\% (BSN, 2008), sementara standar APCC 2007 kadar air dan asam lemak bebas maksimum 0,5\%; dan Philipine National Standars mensyaratkan kadar air dan asam lemak bebas 0,2\% (Satheesh, 2015).

Kadar air dan asam lemak bebas VCO dipengaruhi oleh metode dan skala produksi. Mansor et al., (2012) melaporkan bahwa penggunaan beberapa jenis metode produksi mampu menghasilkan VCO dengan kadar air dan asam lemak bebas yang berbeda-beda. Penggunaan metode fermentasi menghasilkan VCO dengan kandungan air 0,06\% dan asam lemak bebas $0,29 \%$; metode pendinginan pencairan (chiling and thawing method) menghasilkan VCO dengan kandungan air $0,11 \%$ dan asam lemak bebas $0,31 \%$; dan metode enzimatik menghasilkan VCO dengan kandungan air 0,11\% dan asam lemak bebas 0,35\%. Effendi et al., (2012) menjelakan bahwa pada penggunaan enzim bromolin relatif berbeda dengan Mansor et al., (2012) pada penggunaan enzim papain. Penggunaan enzim bromolin menghasilkan VCO dengan kadar air 0,48\% dan kadar asam lemak bebas $0,5 \%$, sedangkan penggunaan enzim papain menghasilkan kadar air 0,11\% dan asam lemak bebas $0,35 \%$, yang memberikan indikasi jenis enzim berpengaruh terhadap kadar air dan asam lemak bebas. Produksi skala industry dengan metode yang sama dengan skala laboratorium menghasilkan VCO dengan kandungan air yang berbeda. Wong dan Hartina (2014) melakukan produksi VCO skala industri menggunakan metode sentrifugasi dan menghasilkan VCO yang mengandung air 0,91\%. Perbedaan kadar air setiap kali produksi VCO disebabkan oleh cara pengambilan fraksi minyak. Kadar air VCO skala laboratorium cenderung lebih kecil daripada skala industri karena pemisahan 
minyak skala laboratorium relative lebih sederhana dibandingkan dengan skala industri (Wong dan Hartina, 2014).

Penurunan kadar air VCO yang diproduksi dengan skala industri dilakukan menggunakan metode Kromatografi Kolom. Adsorben yang digunakan pada umumnya adalah zeolit.Penggunaan zeolit sebagai adsorben menghasilkan VCO dengan rendemen sekitar $60 \%$ relative lebih rendah dibandingkan dengan penggunaan adsorben abu sekam padi yang menghasilkan rendemen $85 \%$. Kadar air VCO pada penggunaan zeolit relativ lebih tinggi $(0,35 \%)$ dibandingkan dengan abu sekam padi yang menghasilkan VCO dengan kadar air 0,25\% menggunakan metode kromotografi kolom adsorbsi (Mappiratu dan ljirana, 2010). Yuliana et al. (2005) menggunakan adsorben tandan kosong kelapa sawit untuk menggurangi asam lemak bebas hingga 0,131\%, sedangkan Irawan et al. (2013) menggunakan adsorben campuran abu sekam padi dan serabut kelapa dan menghasilkan kadar asam lemak bebas 0,29 \%. Mappiratu dan ljirana (2010) memurnikan VCO dengan menggunakan metode kromatogrefi kolom adsorbsi VCO yang dihasilkan menggandung kadar air dan asam lemak bebas 0,09\%. Menurut Toppalar dan Bayrak (1997) abu sekam padi adsorben terbaik untuk menyerap asam lemak bebas. Dengan mengacu pada Standar Nasional Indonesia yang mensyaratkan kadar air $0,2 \%$, penggunaan adsorben abu sekam padi masih perlu pengkajian untuk menurunkan kadar air maksimal $0,2 \%$. Oleh karena itu perlu dilakukan kajian kearah tersebut.

Peneliti telah membuktikan adanya hubungan antara jumlah zat terserap dengan jumlah bahan penyerap (adsorben). Jumlah penggunaan adsorben berbanding lurus dengan jumlah zat yang terserap (Mappiratu dan ljirana, 2010). Fenomena tersebut memberikan indikasi peningkatan jumlah adsorben abu sekam padi dalam kolom kromatografi, semakin tinggi pula jumlah air dan asam lemak bebas yang terserap. Namun demikian, minyak yang terserap juga semakin besar sehingga rendemen VCO akan semakin menurun. Untuk mendapatkan kondisi dimana air dan asam lemak bebas terserap tinggi, sementara penyerapan minyak terbatas, perlu dilakukan kajian kemampuan penyerapan abu sekam padi terhadap air dan asam lemak bebas dalam kolom.

\section{METODE PENELITIAN}

\section{Bahan dan Peralatan}

Bahan yang digunakan dalam penelitian ini adalah santan buah kelapa tua diperoleh dari pasar Masomba Palu, abu sekam padi, $\mathrm{NaOH}$, indikator PP, etanol $95 \%$. Alat yang digunakan pada penelitian ini adalah kromatografi kolom pipa diameter 2,5 inci, 3,0 inci dan panjang $70 \mathrm{~cm}$, ayakan 60 mesh, klem dan statif, buret, dan oven. 


\section{Pembuatan Adsorben dari Sekam Padi (Nurhasni et al., 2014)}

Sekam padi dicuci dengan air sampai bersih dan di jemur di bawah terik matahari hingga kering. Sekam padi yang telah bersih dan kering dimasukan kedalam reaktor pembakaran dan dibakar hingga sekam padi menjadi abu,selanjutnya diayak dengan ayakan 60 mesh, sehingga diperoleh abu sekam padi ukuran partikel 60 mesh. Abu sekam dikemas dalam plastik sebelum digunakan.

\section{Pengolahan VCO kasar (Mappiratu dan Ijirana, 2010)}

VCO kasar diolah dari santan buah kelapa tua (tempurungnnya berwarna coklat). Santan dari 450 buah kelapa tua dibawa ketempat pengolahan VCO dan dimasukkan ke dalam wadah fermentasi, selanjutnya ditambahkan dengan inokulum VCO sebanyak $0,01 \%$ volume per volume. Campuran diinkubasi selama 24 jam, kemudian minyak (VCO kasar) dipisah dari air dan blondo.VCO kasar yang dihasilkan dibebaskan dari blondo yang terikut melalui penyaringan dengan kain saring ukuran 300 mesh.VCO bebas blondo selanjutnya disimpan dalam lemari pendingin sebelum digunakan.

\section{Penentuan Jumlah Adsorben Abu Sekam Padi Dalam Pengolahan VCO Kasar}

Pengolahan VCO dengan abu sekam padi mengikuti metode Fatima dan Sangi (2010) dengan beberapa modifikasi. Kolom yang terbuat dari pipa paralon dengan volume kerja $1100 \mathrm{ml}$ (pipa paralon berdiameter 2,5 dan 3,0 inci, tinggi $70 \mathrm{~cm}$ ) disiapkan sebanyak 5 buah, kemudian diisi dengan abu sekam padi $5 \mathrm{~g}, 10 \mathrm{~g}, 15 \mathrm{~g}, 20 \mathrm{~g}$, $25 \mathrm{~g}$, selanjutnya diisi dengan VCO kasar sebanyak $1100 \mathrm{ml}$ (sesuai volume kerja kolom) dan dibiarkan hingga VCO keluar dari kolom. VCO yang keluar dari kolom ditampung hingga semua VCO dalam kolom keluar, selanjutnya VCO hasil dari kolom ditentukan kadar airnya dengan metode oven dan kadar asam lemak bebas metode titrasi, serta ditentukan rendemen minyak dalam satuan persen volume per volume. Selain itu, adsorben dalam kolom dikeluarkan dan ditimbang untuk mengetahui pertambahan berat setelah penyerapan.

Rendemen VCO hasil penyerapan air dan asam lemak bebas ditentukan menggunakan persamaan :

$$
\text { Rendemen }=\frac{\text { volume VCO hasil pengolahan }}{\text { volume VCO } \text { kasar }} \times 100
$$

\section{Analisis Kadar Air (AOAC, 2002)}

Cawan kosong terlebih dahulu dibersihkan lalu diberi label kemudian dipanaskan dalam oven pada suhu $105^{\circ} \mathrm{C}$ selama 15 menit kemudian ditimbang. Sampel ditimbang didalam cawan seberat 10 gram.Cawan berisi sampel dipanaskan pada suhu $105^{\circ} \mathrm{C}$ selama 3 jam. Setelah itu dipindahkan ke dalam desikator, lalu didinginkan selama 15 menit kemudian di timbang. Cawan beserta sampel dipanaskan kembali dalam oven selama 1 jam hingga diperoleh berat konstan. Kadar 
air dihitung dengan menggunakan persamaan sebagai berikut :

$$
\text { Kadar air }=\frac{(B B+B S)-(B B+B S) *}{B S} \times 100
$$

Keterangan:

$(\mathrm{BB}+\mathrm{BS})=$ Berat cawan + berat sampel sebelum dipanaskan

$(\mathrm{BB}+\mathrm{BS})=$ Berat cawan +berat sampel setelah dipanaskan

BS $=$ Berat sampel sebelum dipanaskan

\section{Analisis Kadar Asam Lemak Bebas (AOAC, 2002)}

Sebanyak $10 \mathrm{gr}$ sampel dimasukan kedalam Erlenmeyer $250 \mathrm{ml}$, selanjutnya dilarutkan dalam pelarut etanol 95\% panas sebanyak $50 \mathrm{ml}$, lalu ditambahkan indicator PP sebanyak 5 tetes. Selanjutnya diaduk menggunakan magnetic stirrer selama 30 detik lalu dititrasi dengan larutan $\mathrm{NaOH} 0,1 \mathrm{~N}$. Titrasi dihentikan jika warna larutan berubah menjadi merah muda yang bertahan tidak kurang dari 10 detik. Kadar asam lemak bebas dihitung menggunakan persamaan sebagai berikut:

$$
\text { Asam lemak bebas }=\frac{V \times T \times A}{m \times 1000} \times 100
$$

Keterangan:

$\mathrm{V}=$ Volume $\mathrm{NaOH}$ yang digunakan untuk titrasi (ml)

$\mathrm{T}=$ Normalitas $\mathrm{NaOH}$

$A=$ Berat Molekul asam laurat

$\mathrm{m}=$ Berat sampel $(\mathrm{gr})$

\section{HASIL DAN PEMBAHASAN}

\section{Virgin Coconut Oil Hasil Adsorbsi}

Salah satu metode untuk mengurangi asam lemak bebas dan kadar air dalam VCO adalah dengan metode adsorbsi menggunakan abu sekam padi.
Abu sekam padi merupakan hasil pembakaran sekam padi yang mengandung 87-97 \% silica, bersifat ringan dan berpori yang dapat membuat minyak menjadi tampak jernih (Krishnarao et al., 2000).

Pada penelitian ini digunakan abu sekam padi sebagai adsorben. pada proses adsorbsi VCO digunakan $1000 \mathrm{ml}$ VCO dengan berat abu sekam padi yang berbeda dan yaitu $5 \mathrm{~g}, 10 \mathrm{~g}, 15 \mathrm{~g}, 20 \mathrm{~g}, 25 \mathrm{~g}$ proses adsorbsi berlangsung selama empat hari hingga diperoleh rendemen VCO antara 80 - 90\% yang terserap pada adsorben antara $10-25 \%$ semakin banyak berat abu sekam padi yang digunakan maka makin sedikit rendemen minyak yang diperoleh seiring banyaknya minyak yang tertampung pada adsorben.

Adsorben abu sekam padi termasuk dalam golongan adsorben alami. Abu sekam padi mengadsorbsi air dan asam lemak bebas secara fisika. Mekanisme proses adsopsi, yaitu molekul atau ion akan meninggalkan larutan dan menempel pada permukaan zat adsorben secara kimia dan fisika. Suatu molekul dapat teradsorbsi apabila gayaadhesi antara molekul adsorbat dengan adsorben lebih besar dibandinkan dengan gaya kohesi dalam masing-masing molekul proses adsorbsi dilakukan untuk mengurangi senyawa bahan organik yang terdapat dalam limbah cair. Proses adsorbsi ini terjadi karena adanya tegangan permukaan dari abu sekam padi, makin besar area yang di sediakan maka makin 
banyak molekul yang diserap (Purbaningtias et al., 2017).

Abu sekam padi sebelumnya telah dimanfaatkan sebagai adsorben oleh Kalapathy et al. (2000), dan mendapatkan bahwa silika film dari abu sekam padi mampu menurunkan kadar asam lemak bebas hingga 20,70 \% dan bilangan peroksida hingga $12,5 \%$, sedangkan silika hasil sintesis mampu menurunkan kadar asam lemak bebas hingga 59\%, bilangan peroksida 93\%. Yuliana et al. (2005) melaporkan bahwa abu sekam padi tanpa aktivasi asam $\left(\mathrm{HCl}\right.$ dan $\mathrm{HNO}_{3}$ ) lebih baik dalam menurunkan asam lemak bebas hingga $63,92 \%$ dan bilangan peroksida $45,64 \%$.

\section{Kadar air VCO}

Kadar air dihitung dari selisih bobot minyak sebelum air dalam minyak di uapkan dengan bobot minyak setelah air dalam minyak di uapkan. Secara keseluruhan, kadar air VCO yang dihasilkan memenuhi persyaratan standar nasional Indonesia (SNI), yaitu maksimal $0,2 \%$.

Parameter penting pada VCo adalah kadar air. Umur simpan VCO akan lebih tinggi saat kadar air rendah. Kadar air sangat mempengaruhi sifat fisikokimia produk pagan, perubahan mikrobiologi, dan enzimatis. Kandungan air yang tinggi dalam bahan menyebabkan daya tahan bahan rendah. Untuk memperpanjang daya tahan suatu bahan, sebagian air dalam bahan harus dihilangkan dengan berbgai cara tergantng dari jenis bahan.

Produk VCO memiliki dua jenis kandungan air, yaitu air bebas dan air terikat. Air terikat pada VCO merupakan molekul air yang terikat secara kimia dengan rantai trigliserida. Sebagian besar penyusun minyak adalah trigliserida maka diduga air yang terdapat pada VCO adalah air terikat. Air bebas yang terdapat pada VCO berada dalam keadan bebas dan tidak berikatan dengan trigliserida (Nodjeng et al., 2013).

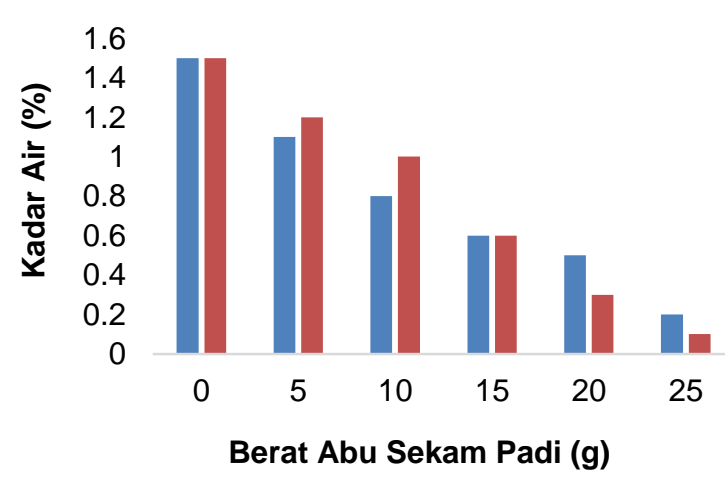

- kolom adsorbsi 2,5 - kolom adsorbsi 3,0

Gambar 1 Kadar air VCO hasil adsorbsi

Hubungan interaksi antara komponen abu sekam padi dengan kadar air pada VCO dapat dilihat dari grafik diatas semakin banyak abu sekam padi maka akan menghasilkan kadar air yang semakin rendah hal ini disebabkan karena adanya gugus $\mathrm{SiO}_{2}$ yang memiliki sifat hidrofilik (suka air) yang mampu mengikat air sehingga pada grafik diatas semakin banyak abu sekam padi yang digunakan pada proses adsorbsi akan mengurangi kadar air pada VCO. Abu sekam padi mengandung gugus $\mathrm{SiO}_{2}$ yang memiliki 
sifat hidrofilik sehinggah dapat mengikat air melalui pembentukan ikatan rangkap hldrogen. Kadar air VCO semakin menurun seiring bertambahnya massa abu sekam padi. Kadar air yang terendah diperoleh pada penggunaan abu sekam padi $25 \mathrm{~g}$ pada kolom diameter 3.0 inci $(0,1 \%)$. Nilai ini memenuhi standar maksimum yang dipersyaratkan SNI, yaitu $0,2 \%$. VCO sebelum perlakuan tampak lebih keruh karena memiliki nilai kadar air lebih tinggi dari 0,2 \%. Hal ini membuktikan bahwa penggunaan abu sekam padi baik digunakan untuk penurunan kadar air vco.

Berdasarkan hasil analisis sidik ragam menggunakan SPSS dengan taraf kepercayaan 95\% $(\alpha=0,05)$ ditunjukan pada table ANOVA dengan nilai sign ( $p$ value) $<\alpha$ yang menunjukkan bahwa berat adsorben abu sekam padi berpengaruh nyata terhadap kadar air yang dihasilkan, Oleh karena itu, dapat dilakukan analisis lanjut dengan uji Duncan untuk menentukan berat terbaik adsorben abu sekam padi. Hasil uji lanjut Duncan menunjukan terbentuk 6 kolom yang dimana berat $25 \mathrm{~g}$ terisi pada kolom subset pertama, berat $20 \mathrm{~g}$ terisi pada kolom subset kedua, berat $15 \mathrm{~g}$ terisi pada kolom subset ketiga, berat $10 \mathrm{~g}$ terisi pada kolom subset keempat, berat $5 \mathrm{~g}$ terisi pada kolom subset kelima dan berat 0 (VCO Sebelum perlakuan) terisi pada kolom subset keenam. Berdasarkan data tersebut dapat disimpulkan bahwa berat adsorben abu sekam padi $5 \mathrm{~g}, 10 \mathrm{~g}, 15 \mathrm{~g}$, 20g, $25 \mathrm{~g}$ berbeda nyata satu sama lain. Dengan demikian, berat adsorben abu sekam padi $25 \mathrm{~g}$ memiliki kadar air terendah.

Mutu VCO telah memenuhi standar yang telah dipersyaratkan standar mutu minyak kelapa murni berdasarkan SNI 7381:2008 yaitu 0,2\%. Penelitian sebelumnya (pratiwi dkk, 2016) abu sekam padi mampu menurunkan kadar minyak kelapa yaitu $0,07 \%$ dan irawan, dkk (2013), diperoleh kadar air 0,046 \%.

\section{Asam Lemak Bebas}

Asam lemak bebas menjadi parameter uji yang penting pada penentuan mutu VCO. Asam lemak bebas dapat berasal dari hasil hidrolisis dari senyawa trigliserida pada VCO. Kehadiran air akan semakin mempercepat reaksi hidrolisis dari VCO menjadi asam lemak bebas (Ayu dan Farida, 2010).

Asam lemak bebas atau free fatty acid (FFA) juga dapat terbentuk dari proses oksidasi selama pengolahan dan penyimpanan minyak. Kadar asam lemak pada produk pangan dengan kadar $>0,2 \%$ (berdasarkan berat lemak) akan menimbulkan rasa yang tidak enak pada produk VCO dan juga dapat menjadi racun bagi tubuh manusia (Ketaren, 1986).

Hubungan interaksi antara komponen abu sekam padi dengan kadar asam lemak bebas VCO semakin banyak abu sekam padi maka akan menghasilkan kadar asam lemak bebas yang semakin 
rendah hal ini disebabkan karena adanya fisisorpsi melalui ikatan hidrogen dari oksigen karbonil dari asam lemak bebas ke hidrogen silanol pada antar muka butiran silika, oksigen karbonil dari asam lemak bebas dapat teradsorpsi di permukaan dengan membentuk ikatan hidrogen dengan hidrogen silanol Toppalar dan Bayrak (1997).

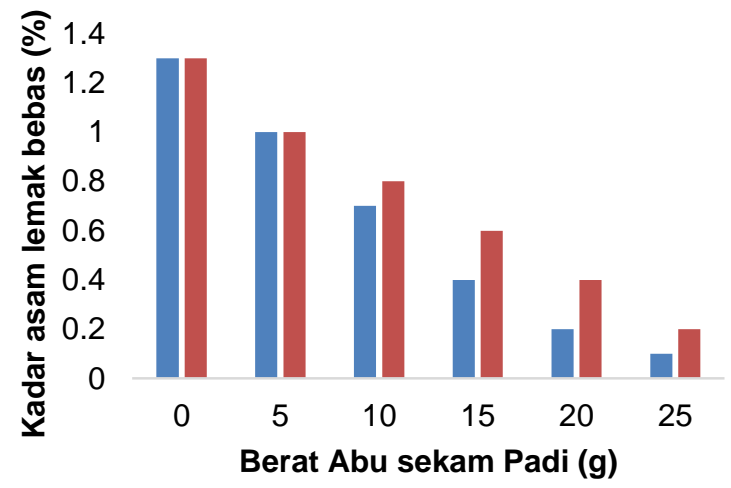

घkolom adsorbsi 2,5 घ kolom adsorbsi 3,0

Gambar 2 Kadar asam lemak bebas VCO hasil adsorbsi

Hasil penelitian menunjukkan bahwa kemampuan abu sekam padi untuk menyerap asam lemak bebas cukup tinggi. Terbukti dari data yang diperoleh, asam lemak bebas sebelum di adsorbsi memiliki nilai sebesar $1,3 \%$, sedangkan dari setiap perlakuan adsorbsi untuk variasi berat abu sekam padi pada pipa diameter 2,5 inci mengalami penurunan asam lemak bebas sebesar $0,1 \%$ pada penggunaan abu sekam padi $25 \mathrm{~g}$, dan pada pipa diameter 3,0 inci juga mengalami penurunan kadar asam lemak bebas $0,2 \%$ pada penggunaan abu sekam padi $25 \mathrm{~g}$ (Gambar 2).

Berdasarkan hasil analisis sidik ragam menggunakan SPSS dengan taraf kepercayaan 95\% $(\alpha=0,05)$ ditunjukan pada table ANOVA dengan nilai sign ( $p$ value) $<\alpha$ yang menunjukkan bahwa berat adsorben abu sekam padi berpengaruh nyata terhadap kadar asam lemak bebas (ALB) yang dihasilkan. Oleh karena itu, dapat dilakukan analisis lanjut dengan uji Duncan untuk menentukan berat terbaik adsorben abu sekam padi. Dari hasil Duncan menunjukan terbentuk 6 kolom yang dimana berat $25 \mathrm{~g}$ terisi pada kolom subset pertama, berat $20 \mathrm{~g}$ terisi pada kolom subset kedua, berat $15 \mathrm{~g}$ terisi pada kolom subset ketiga, berat $10 \mathrm{~g}$ terisi pada kolom subset keempat, berat $5 \mathrm{~g}$ terisi pada kolom subset kelima dan berat 0 (VCO sebelum perlakuan) terisi pada kolom subset keenam. Berdasarkan data tersebut dapat disimpulkan bahwa berat adsorben abu sekam padi $5 \mathrm{~g}, 10 \mathrm{~g}, 15 \mathrm{~g}$, $20 \mathrm{~g}, 25 \mathrm{~g}$ berbeda nyata satu sama lain. Dengan demikian, berat adsorben abu sekam padi $25 \mathrm{~g}$ memiliki kadar asam lemak bebas terendah.Berdasarkan data grafik 4.4 terjadi penurunan asam lemak bebas karena adanya zat-zat seperti air terikat pada abu sekam padi sehingga pembentukan oksidasi pada minyak terhambat.

Kadar asam lemak bebas dari produk VCO yang dihasilkan telah memenuhi standar SNI 7381:2008, yaitu $<0,2 \%$. Penelitian sebelumnya oleh Kalapathy et al. (2000) dengan menggunakan abu sekam padi dalam bentuk silikat film, mampu menurunkan 
kandungan asam lemak bebas dari 0,8\% menjadi $0,55 \%$.

\section{Rendemen VCO}

Rendemen minyak merupakan persentase VCO yang di hasilkan dari hasil penyerapan air dan asam lemak bebas. Rendemen di hitung untuk mengetahui banyaknya VCO yang di peroleh dari proses adsorbsi asam lemak bebas dan air. Rendemen ditentukan dengan menentukan volume VCO hasil penyerapan dibandingkan dengan volume VCO yang masuk kekolom adsorbsi.

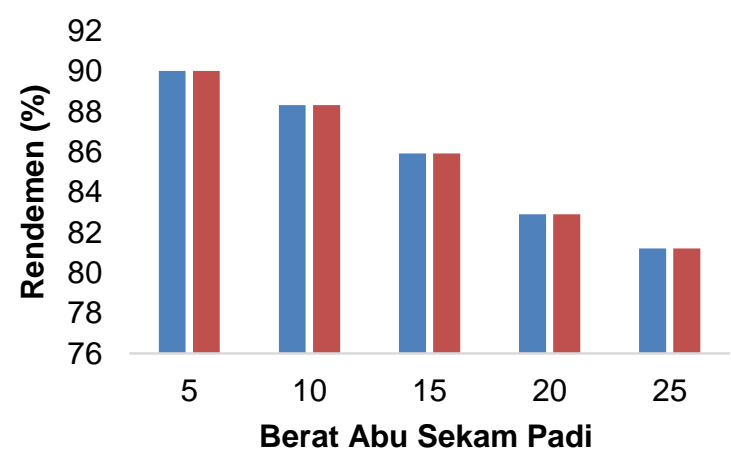

- kolom adsorbsi 2,5 nolom adsorbsi 3,0

Gambar 3 Grafik rendemen VCO hasil adsorbsi

Kolom 2,5 inci memiliki rendemen terendah yaitu $81.2 \%$ pada berat abu sekam padi $25 \mathrm{~g}$ dan pada kolom 3.0 rendemen abu sekam padi terendah 83,6 pada berat abu sekam padi $25 \mathrm{~g}$ (Gambar 3).

Berdasarkan hasil analisis sidik ragam menggunakan SPSS dengan taraf kepercayaan 95\% $(\alpha=0,05)$ ditunjukan pada table ANOVA dengan nilai sign ( $p$ value) < a yang menunjukkan bahwa berat adsorben abu sekam padi berpengaruh nyata terhadap rendemen yang di hasilkan, oleh Karena itu dapat dilakukan analisis lanjut dengan uji Duncan untuk menentukan berat terbaik adsorben abu sekam padi. Dari hasil Duncan menunjukan terbentuk 5 kolom yang dimana berat $25 \mathrm{~g}$ terisi pada kolom subset pertama, berat $20 \mathrm{~g}$ terisi pada kolom subset kedua, berat $15 \mathrm{~g}$ terisi pada kolom subset ketiga, berat $10 \mathrm{~g}$ terisi pada kolom subset keempat, berat $5 \mathrm{~g}$ terisi pada kolom subset kelima. Berdasarkan data tersebut dapat disimpulkan bahwa berat adsorben abu sekam padi $5 \mathrm{~g}, 10 \mathrm{~g}, 15 \mathrm{~g}$, 20g, $25 \mathrm{~g}$ berbeda nyata satu sama lain. Dengan demikian, berat adsorben abu sekam padi $25 \mathrm{~g}$ memiliki rendemen yang paling rendah tetapi tidak kurang dari $80 \%$. Menurut penelitian sebelumnya (Mappiratu dan ljirana, 2010), makin banyak adsorben yang digunakan, semakin banyak pula minyak terserap dan rendemen semakin menurun tidak kurang dari $80 \%$.

\section{KESIMPULAN}

Adsorben terbaik yang menghasilkan kadar air 0,2\% diperoleh pada pipa kolom 2,5 inci dengan berat adsorben $25 \mathrm{~g}$. Adsorben terbaik yang menghasilkan asam lemak bebas 0,1\% diperoleh pada pipa kolom diameter 2,5 inci dengan berat adsorben $25 \mathrm{~g}$. Rendemen terbaik diperoleh kolom 2,5 inci $81,2 \%$ sesuai dengan standar mutu. 


\section{DAFTAR PUSTAKA}

Abdurrahman HN, Mohammed FS, Yunus RM, Arman A. 2009. Demulsification of Virgin Coconut Oil by Centrifugation Method: a feasibility study. International Journal of Chemical Technology, 1:59-64.

Nodjeng, M., Fatimah, F., Rorong, J A. 2013. Kualitas Virgin Coconut Oil (VCO) Yang Dibuat Pada metode Pemanasan Bertahap sebagai Minyak Goreng Dengan Penambahan Wortel (Daucus carrota L.). Jurnal Ilmiah Sains, 13(2).

AOAC International. 2002. Official Methods of Analysis of AOAC Internationa. $17^{\text {th }}$ edition. Volume 2, Ch 41:19-20.24-26. Gaitherburg, Maryland, USA.

Ayu, Dewi Fortuna dan Farida Hanum Hamzah.2010. Evaluasi Sifat Fisika -Kimia Minyak Goreng Yang digunakan oleh Pedagang Makanan di Kecamatan Tanpan Kota Pekan Baru. SAGU, 9(1): 414.

Badan Standarisasi Nasional. 2008. Standar Mutu Minyak Kelapa Murni. SNI 7381: 2008. Jakarta: BSN.

Fatimah, F., dan Sangi, M E C. 2010. Kualitas Pemurnian Virgin Coconut Oil (VCO) Menggunakan Beberapa Adsorben. Chem.Prog., 3(2): 65-69.

Fatwatun, N R., Chusnah, K., Pramudono, B. 2013. Pembuatan Virgin Coconut Oil (VCO) : Pemecahan Emulsi Dengan Metode Ultrasonik. Jurnal Teknologi Kimia dan Industri, 2(4): 184-188.

Handayani, R., Sulistiyo, J., Rahayu, R D. 2009. Extraction of Cococnut Oil (Cocos nucifera L.) through
Fermentation System. Biodiversitas, 5(3): 151-157.

Irawan, C., Awalia, T N., Utami, S. 2013. Pengurangan Kadar Asam Lemak. Bebas (FFA) Dan Warna Dari Minyak Goreng Bekas dengan Proses adsorbsi menggunakan Campuran Serabut Kelapa dan Sekam Padi. KONVERSI, 2(2).

Kalapathy, U., Proctor, A., and Shultz, J. 2000. A Simple Method for Production Of Pure Silica From Rice Hull Ash. Bioresour. Thecnol 73: 257-262.

Ketaren, S. 1986. Pengantar Teknologi Minyak dan Lemak Pangan. Jakarta: UI-Press.

Krishnarao R. V., Subrahmanyam J., Kumar, T. J. 2000. Studies on the formation of black in rice husk silica ash. J. Ceramic Society, 21: 99 104.

Mansor, T. S. T., Che Man, Y, B., Shuhaimi, M., Afiq, M. J. A., dan Nurul, F. K. M. 2012. Physicocemical properties of virgin coconut oil extracted from diferrent processing methods. International Food Research Journal, 19(3), 837845.

Mappiratu dan ljirana. 2010. Pembuatan metyl ester asam lemak rantai sedang dan rantai panjang serta pemurnian minyak kelapa murnl, Jurnal Penelitian Hasi Hutan, 28(4):415-426.

Nurhasni., Hednrawati., Saniyyah, N. 2014. Sekam Padi untuk Menyerap Ion Logam Tembaga dan Timbal dalamAir Limbah. Jurnal Kimia Valensi, 4(1).

Proctor, A. and Palaniappan.1989. Soy Oi Lutein adsorption by rice hull ash. JAOCS, 66(11). 
Pratiwi, L., A. Fhudoli. 2016. Design And Optimation of self Nanoemulsifiying Drug Delivery Sytem. Journal OF Pharmatech, 9.

Purbaningtias, $\mathrm{T}$ E., Kurniawati, P., Wiyantoko, B., Prasetyoko, D., Suprapto. 2017. Pengaruh Waktu Aging Pada Modifikasi Pori Zeolit Alam Dengan Cetyl Trimethylamonium bromide. Jurnal Sains dan Teknologi, 6(2): 321-330.

Toppalar, H.,Bayrak,Y. 1997. Investigation of adsoption isotherms of Myristic, Palmitic, and Stearic acids on Rice Hull Ash. Turk J Chem., 23: 193198.

Satheesh, N., P rasad, N.B.L. 2014. Production of Vigin Coconut Oil By Different Wet Methods And Determination of Quality Parameters, Ann. Food Sci. Technol., 15(1): 10-19.

Wong, Y C., Hartina, H. 2014. Virgin Cococnut Oil Production by Centrifugation method. Orient. J. Chem., 30:237-245.

Yuliana, et al. 2005. Penggunaan Adsorben untuk Mengurangi Kadar Free Fatty Acid, Peroxide Value dan Warna Minyak Goreng Bekas. Jurnal Teknik Kimia Indonesia, 4(2): 212-218. 